\author{
Research Article \\ www.ijrap.net
}

\title{
PHARMACEUTICAL STANDARDIZATION AND CHARACTERIZATION OF AYURVEDIC HERBOMINERAL COMPOUND SANDHIVATARI GUTIKA
}

\author{
K. Aruna Gayithri ${ }^{1 *}$, K.V. RamSubbarao ${ }^{2}$, K. Ramanjaneyulu ${ }^{3}$ \\ ${ }^{1}$ Assistant Professor, P.G. Department of Kaya Chikitsa, Dr. B.R.K.R. Government Ayurvedic College Hyderabad, \\ Telangana, India \\ ${ }^{2}$ Assistant Research Officer, Government Research Department (Ayurveda) Erragadda, Hyderabad, Telangana, India \\ ${ }^{3}$ Assistant Professor, Vishnu Institute of Pharmaceutical Sciences and Research, Narsapur, Medak, Telangana, India
}

Received on: 19/02/15 Revised on: 12/03/15 Accepted on: 12/04/15

\begin{abstract}
*Corresponding author
Dr. K. Aruna Gayithri, Assistant Professor, P.G. Department of Kaya Chikitsa, Dr. B.R.K.R. Government Ayurvedic College Hyderabad, Telangana, India E-mail: subbaraoketharaju@ymail.com

DOI: $10.7897 / 2277-4343.06364$

\section{ABSTRACT}

Sandhivatari gutika an Ayurvedic herbomineral formulation (a group of three drugs indicated in sandhigatavata) is referred in Bharata Baishagya ratnakara. The prepared drug was subjected to certain organoleptic tests, TLC studies, preliminary phytochemical screening and experimental studies. The $\mathrm{pH}$ of the compound was found to be 4.50 and acidic in nature. The sample was negative for carbohydrates, starch, alkaloids, steroids, proteins and positive to tests of glycosides, tannins and phenolics. Metal concentration present in this compound was evaluated by using Wavelength Dispersive X - Ray Fluorescence (WD-XRF) spectrometry. A total of 15 elements i.e. O, Na, Mg, Al, Si, P, S, Cl, K, Ca, Mn, Fe, Cu, As and $\mathrm{Hg}$ from medicine were identified. These are all useful for the living being. Among 15, 8 are macro-nutrients $(\mathrm{Na}, \mathrm{Mg}, \mathrm{Al}, \mathrm{Si}, \mathrm{P}, \mathrm{S}, \mathrm{K}, \mathrm{Ca})$ and 3 are defined as micro-nutrients $(\mathrm{Mn}, \mathrm{Fe}, \mathrm{Cu}$ ). The method was measured by Fast-Vac - 34. It was observed that the formulation contains $\mathrm{O}, \mathrm{Cl}, \mathrm{As}$ and $\mathrm{Hg}$.
\end{abstract}

Key words: Sandhivatari gutika, WD- XRF, Phytochemical screening.

\section{INTRODUCTION}

Ayurveda is one among the other glorious proud of India. Although it is very old yet useful even in this era. It has enormous treasure of life science for all. Several achievements of today's advancing medical science are already incorporated in the treatise of Indian medicine. But as these concepts were suggested several centuries ago so, in view of availability of newer methods of investigations and technology in modern age, these concepts need critical analysis, comments, elaborative and scientific explorations to bridge the gap existing between Ayurveda and western modern medical sciences. In this context drugs advocated useful in different conditions need evaluation in present times along with probable mode of action to prove their efficacy on modern parameters. Thus pharmaceutical standardization of Ayurvedic medicine is necessary to ensure quality, safety and efficacy of drugs.

\section{MATERIALS AND METHODS}

The study was undertaken at Govt. Ayurvedic Hospital, Erragadda, Hyderabad, Telangana, India.
Laboratory of X-ray crystallography, Indian institute of chemical technology, Hyderabad, Telangana, India and Varun Herbals, DSIR-SIRO, recognized by Government of India, Hyderabad, Telangana, India.

\section{Mode of preparation}

\section{Table 1: Composition of Sandhivaataari gutika}

\begin{tabular}{|c|c|c|}
\hline Name of the Drug & Latin Name & Parts Used \\
\hline Hingula (purified) & Cinnabar & - \\
\hline Guggulu (purified) & Commiphora mukul & Gum/Resin \\
\hline Bola & Commiphora mol mol & Resin \\
\hline
\end{tabular}

\section{Purification of hingula and guggulu}

The purification of the hingula and guggulu (Red oxide of mercury and Commiphora mukul) had two stages viz.

\section{Collection of raw material}

Hingula, Guggulu and Bola were purchased from herbal shop, Begumbazar, Hyderabad, India 
Table 2: Shodana (purification)

\begin{tabular}{|c|c|c|c|}
\hline $\begin{array}{c}\text { Name of the } \\
\text { drug }\end{array}$ & Material & Apparatus & Purification procedure \\
\hline Hingula & $\begin{array}{c}\text { 1.Hingula as required. } \\
\text { 2. Lemon Juice-Q.S. }\end{array}$ & $\begin{array}{c}\text { 1. Morter and Pestle. } \\
\text { 2. Laddle. }\end{array}$ & $\begin{array}{c}\text { Hingula made to powder. This powder is pounded in lemon juice. The } \\
\text { process is repeated for 7 times }{ }^{1 .}\end{array}$ \\
\hline Guggulu & $\begin{array}{c}\text { Guggulu - 1 Part. } \\
\text { Guduchi - 1 part. } \\
\text { Triphala - 1 Part. } \\
\text { Water - 1 part. }\end{array}$ & $\begin{array}{c}\text { Khalva yanthra } \\
\text { Angara kosti } \\
\text { Stainless steel } \\
\text { vessel, Cloth } \\
\text { Laddle, Iron rod. }\end{array}$ & $\begin{array}{c}\text { Triphala and Guduchi are coarsely powdered. This powder is boiled with 8 } \\
\text { time's water till it is reduced to 1/4h. Guggulu is coarsely pounded and is tied } \\
\text { as bundle in a cloth. This bundle is hanged to a rod in such a position that the } \\
\text { bundle tie immersed in the decoction. The decoction is heated till all the } \\
\text { guggulu in the bundle is collected into the decoction after getting melted due } \\
\text { to boiling of decoction. The decoction with guggulu is taken in a separate } \\
\text { vessel and is heated over moderate flame till all the moisture is evaporated } \\
\text { and only guggulu in the farm on black paste is left alone }\end{array}$ \\
\hline
\end{tabular}

\section{Preparation of sandhivaataari gutika}

All the herbs were taken from herbal shops located at Begum bazar, Hyderabad.The purified sample of Hingula and Guggulu were from the procedures detailed above ${ }^{3}$. The drugs mentioned in the Table 1 (purified Hingulam, Guggulu and Bola) were made into powder. This powder was pounded in godugdha, (cow's milk) for one day. Afterwards dried and powdered. Made into pills in the dose of $125 \mathrm{mg}$.

\section{Analytical study of sandhivaataari gutika Organoleptic tests}

Texture - Fine powder

Odour - Aromatic

Colour - Reddish Brown

Taste - Bitter ${ }^{4}$

\section{Physicochemical analysis}

$\mathrm{pH}^{-} \quad 4.50$

Moisture content - $\quad 4.7 \%$

Total Ash - $11.25 \%{ }^{4}$

\section{Thin Layer Chromatography (TLC)}

The TLC of sample was done by using solvent systemToluene: chloroform: Methanol and spraying reagent vanillin and sulphuric acid and detected 3 spots with $\mathrm{Rf}$ values 0.97(Brown), 0.54(Brown) and 0.25(Blue). Monograph was not available to Sandhivaataari gutika in volumes of Ayurvedic Pharmacopeia of India and in Ayurvedic Formulary of India Vol.I and II for reference of analysis till date ${ }^{4}$.

\section{Phytochemical screening}

The sample was negative for carbohydrates, starch, alkaloids, steroids, proteins and positive to tests of glycosides, tannins and phenolics ${ }^{5,6,7}$.

\section{Wavelength Dispersive-X ray Fluorescence (WD-XRF) Spectrometry}

One gram of each original sample was taken in an aluminium cup and pressed into a pellet using a hydraulic press (HERZOG, type: TP40\2D) at 15 tons to obtain pellet of moderate thickness. Samples were characterized by using WD-XRF spectrometer (Bruker S4 Pioneer), equipped with a $4 \mathrm{KW}, \mathrm{Rh}$ anode $\mathrm{x}$-ray tube with six analyzer crystals [Lif (220), PET, OVO-55, OVO-N, OVO-C and OVO-B]. It has sealed proportional counter for lighter elements and a scintillation counter for heavy element detection. X-ray exposure time and power conditions were adjusted for each element by a precalibrated program. The method was measured by FastVac. $34^{8}$.

\section{RESULTS AND DISCUSSION}

Table 3: Characterization of sandhivaataari gutika by using WDXRF spectrometry

\begin{tabular}{|c|c|c|c|c|c|}
\hline $\mathrm{O}$ & $\mathrm{Na}$ & $\mathrm{Mg}$ & $\mathrm{Al}$ & $\mathrm{Si}$ & $\mathrm{Mn}$ \\
\hline $8.8 \times$ & $0.262 \%$ & $1.036 \%$ & $0.136 \%$ & $0.695 \%$ & \multirow{2}{*}{$0.0570 \%$} \\
\cline { 1 - 5 } $\mathrm{P}$ & $\mathrm{S}$ & $\mathrm{Cl}$ & $\mathrm{K}$ & $\mathrm{Ca}$ & \\
\cline { 1 - 5 } $0.206 \%$ & $1.891 \%$ & $0.763 \%$ & $3.405 \%$ & $7.695 \%$ & \\
\cline { 1 - 5 } $\mathrm{Fe}$ & $\mathrm{Cu}$ & $\mathrm{As}$ & $\mathrm{Hg}$ & $\mathrm{Sum}$ & \\
\cline { 1 - 5 } $0.5992 \%$ & $0.0654 \%$ & $0.6437 \%$ & $4283 \%$ & $69.16 \%$ & \\
\hline
\end{tabular}

Table 3 shows the concentration of various elements determined in Sandhivatari gutika by WD-XRF. Out of 15 elements listed, which are considered to be essential to the life systems, 8 are macro-nutrients $(\mathrm{Na}, \mathrm{Mg}, \mathrm{Al}, \mathrm{P}, \mathrm{S}, \mathrm{K}$ and $\mathrm{Ca}$ ) and 3 are defined as micro-nutrients $(\mathrm{Mn}, \mathrm{Fe}, \mathrm{Si}$, $\mathrm{Cu}$ ). The concentration of two heavy elements $\mathrm{As}$, and $\mathrm{Hg}$ in the drug were $0.6437 \%$ and $42.83 \%$.

Arsenic, one of the two heavy metals is present in the sample is currently used as a drug in the form of arsenic trioxide to treat acute leukemia. The concentration of it in sample was 0.643. Mercury is a toxic element, it's concentration in sample was $42.83 \%$ as determined by WD-XRF

Magnesium assures the strength and firmness of bones and makes teeth harder. Since magnesium participates in an astonishing array of biochemical reactions, it's no surprise that it's essential for healthy bones and teeth. Most notably, adequate magnesium is essential for absorption and metabolism of calcium. The use of calcium supplements in the face of a magnesium deficiency can lead to calcium deposition in the soft tissues, such as the joints, where it can promote arthritis, or in the kidney, contributing to kidney stones 9 . It's concentration in sample was $1.036 \%$ as determined by WD-XRF ${ }^{9}$ 
Calcium is an essential component of bone, cartilage and the crustacean exoskeleton. Calcium is essential for the normal clotting of blood, by stimulating the release of thromboplastin from the blood platelets. Calcium is an activator for several key enzymes, including pancreatic lipase, acid phosphates, cholinesterase, ATP, and succinic dehydrogenase.Through its role in enzyme activation, calcium stimulates muscle contraction (ie. promotes muscle tone and normal heart beat) and regulates the transmission of nerve impulses from one cell to another through its control over acetylcholine production. Calcium, in conjunction with phospholipids, plays a key role in the regulation of the permeability of cell membranes and consequently over the uptake of nutrients by the cell. Calcium is believed to be essential for the absorption of vitamin B12 from the gastro-intestinal tract. It's concentration in sample was $7.695 \%$ as determined by WD-XRF ${ }^{10}$.

Potassium is a very important macro element for proper functioning of all cells, tissues, organs in the human body. It is also an electrolyte and a substance that conducts electricity in the body along with sodium chloride, calcium and magnesium. Potassium is crucial to heart function and plays key role in skeletal and smooth muscle contraction. Studies shows a positive link between a diet rich in $\mathrm{K}$ and bone health, particularly among elderly women, suggesting that increasing consumption of foods rich in $\mathrm{K}$ may play a role in Osteoporosis prevention . Some studies have linked low levels of $\mathrm{K}$ in the diet with high blood pressure. There is evidence that $\mathrm{K}$ supplements will cause a slight drop in blood pressure. Other studies shows that increase in potassium intake reduce the risk of dying from cardio vascular diseases. Researchers suspect this is largely due to potassium blood pressure lowering effect. The most important use of $\mathrm{K}$ is to treat the symptoms of hypokalaemia ${ }^{11}$. The concentration of potassium in the sample was found to be $3.405 \%$ by WD-XRF.

Phosphorus is an essential nutrient for human and animal life. It is fundamental to growth, maintenance, and repair of all body tissues, and is necessary, along with calcium and magnesium, for proper growth and formation of bones in infants and children. Sufficient phosphorus intake is important throughout life to ensure the proper balance of essential minerals in order to promote remineralization of bones and teeth to keep them in a healthy state. Osteoporosis is a common form of bone disease, and is characterized by low bone mass and deterioration of the bone. In order to ensure the most efficient use of the calcium ingested to prevent osteoporosis, it is also important to consume at least 700 milligrams of phosphorus daily. If the ratio of calcium-tophosphorus is too high, proper bone growth cannot occur. These results showed that calcium and phosphorus are codependent, and that both minerals are critical to support soft tissue and bone growth ${ }^{12}$. The concentration of phosphorus determined in the sample was $0.206 \%$ by WD-XRF.
Sulphur is an essential component of several key amino acids (methionine and cystine), vitamins (thiamine and biotin), the hormone insulin, and the crustacean exoskeleton. As the sulphate, sulphur is an essential component of heparin, chondroitin, fibrinogen and taurine. Several key enzyme systems such as coenzyme A and glutathione depend for their activity on free sulphydryl (SH) groups. Sulphur is believed to be involved in the detoxification of aromatic compounds within the animal body ${ }^{13}$. The concentration of sulphur determined in the sample was $1.891 \%$ by WD-XRF.

Manganese functions in the body as an enzyme activator for those enzymes that mediate phosphate group transfer (i.e. phosphate transferases and phosphate dehydrogenases), particularly those concerned with the citric acid cycle including arginase, alkaline phosphatase and hexokinase. Manganese is an essential component of the enzyme pyruvate carboxylase. As a cofactor or component of several key enzyme systems, manganese is essential for bone formation (re. mucopolysaccharide synthesis), the regeneration of red blood cells, carbohydrate metabolism, and the reproductive cycle ${ }^{14}$. The concentration of manganese determined in the sample was $0.0570 \%$ by WD-XRF.

Copper is an essential component of numerous oxidationreduction enzyme systems. For example, copper is a component of the enzymes cytochrome oxidize, uricase, tyrosinase, superoxide dismutase, amine oxidase, lysyl oxidase, and caeruloplasmin. As a component of the enzyme caeruloplasmin (ferroxidase), copper is intimately involved with iron metabolism, and therefore hemoglobin synthesis and red blood cell production and maintenance. Copper is also believed to be necessary for the formation of the pigment melanin and consequently skin pigmentation, for the formation of bone and connective tissue, and for maintaining the integrity of the myelin sheath of nerve fibres ${ }^{15}$. The concentration of copper determined in the sample was $0.0654 \%$ by WD-XRF.

The compound was prepared and analyzed after general and special shodana (means purification of minerals, metals and poisonous herbal drugs in order to remove inherent impurities and poisonous effects) according to the textual reference. So, the heavy metals like $\mathrm{Hg}$ and As present in the compound mayn't produce any adverse events or toxic symptoms.

\section{CONCLUSION}

Herbomineral or mineral preparations revolutionized the entire medical system since medieval period. The adoption of modern knowledge in terms of any analytical studies facilitates acceptability of the system to a greater extent. Basing on the observations recorded during the course of study of Sandivaataarigutika in pharmaceutical and analytical aspects the following conclusions are drawn. 
For general and special purification of Hingula the procedure mentioned in Rasa Ratna Samuchaya may be considered as standard procedure.

The presence of bioactive compounds (after phytochemical tests) in the drug has been linked to their activities against disease causing microorganisms and also offering the plants to protect themselves against infections by pathogenic microorganisms. The 15 elements present in the sample which were confirmed by WD-XRF spectrometry were considered to be essential to the life.

\section{ACKNOWLEDGEMENT}

It is pleasure to express our deepest sense of gratitude to Mr.G.Y.S.K. Swamy and K. Ravi Kumar, laboratory of X-ray crystallography Indian institute of chemical technology. Hyderabad, India and Principal, Vishnu Institute of Pharmaceutical Sciences and Research, Narsapur, Medak, Telangana, who helped us to complete the Analytical studies quickly.

\section{REFERENCES}

1. Dr. Indra Deva Tripathi,Rasaratna Samuchaya, Chaukamba sanakrit samsthan Varanasi, Edn2009, Hindi, Pp.41.

2. Dr. Nisteshwar, Dr. A. Anil Kumar, Dr. PVNR. Prasad, Selected Ayurvedic formulations, Choukamba oriantalia,varanasi, edtn.Ist.2007,Pp 222.

3. Dr. Naaginidas Chaganlal Shaw, Rasavaidya, Bharatha bhaishagya ratnakara,rasaprakarana, volume:V. edtn.2005, Hindi version,Pp.304.

4. Varun herbals, DSIR-SIRO, recognized by Govt. of India, Hyderabad-500001, Telangana.

5. Kokate C.K. Practical pharmacognosy, Vaiiabha prakashan New Delhi, Preliminary phytochemical Screening, Chapter 6,Pp106-111.
6. Shailendra S.Gurav, Vijay D.Gulkari, Nandkishore J.Duragkar and Aarun T.Patil International Journal of Pharmacy and Technology. 2008;7(1):21-24.

7. Khandelwal K.R. Practical pharmacognosy. Nirali prakashan Pune.Techniques and experiments, chapter 40,17thedtn, Pp 149153.

8. K.V. Ram Subbarao and Naidu. M.L. Pharmaceutical Standardization and Characterization of Ayurvedic Herbomineral compound Trushanadiloha. Int. J. Res. Ayurveda Pharm. 2011; 2(5): 1438-1440.

9. www.better bones. Com/ bone nutrition/ magnesium. aspx. Nutrition andbone health- key minerals for bone healthmagnesium. Accessed on 6/3/15

10. 6 Essential nutrients- Minerals www.fao.org/docrep/field/003/ ab470e/ab470e06.htm. Title: The nutrition and feeding of farmed fish and shrimp: a training manual,I : Accessed on 8/3/15.

11. umm.edu./medical references /health/ medical/ alt med/ supplement/ Potassium. Accessed on 7/3/15.

12. Phosphate Facts; Phosphorus- Essential to Bone Health. www.phosphates facts. Org /Pdfs/ Phosphorus Essential. Pdf Accessed on $7 / 3 / 15$.

13. 6 Essential nutrients- Minerals www.fao.org/docrep/field/003 /ab470e/ab470e06.htm. Title:The nutrition and feeding of farmed fish and shrimp:a training manual, I : Accessed on 8/3/15.

14. 6 Essential nutrients- Minerals www.fao.org/docrep/field/003 /ab470e/ab470e06.htm. Title:The nutrition and feeding of farmed fish and shrimp: a training manual, I: Accessed on 8/3/15.

15. 6 Essential nutrients- Minerals www.fao.org/docrep/field/003/ ab470e/ab470e06.htm.

\section{Cite this article as:}

K. Aruna Gayithri, K.V. RamSubbarao, K. Ramanjaneyulu. Pharmaceutical standardization and characterization of Ayurvedic herbomineral compound sandhivatari gutika. Int. J. Res. Ayurveda Pharm. 2015;6(3):321-324 http://dx.doi.org/10.7897/2277-4343.06364 